\title{
Tumorigenic Potential of Dimethyl Sulfoxide, Anthracene in Fish and Anthracene in Dimethyl Sulfoxide in Rattus Norvegicus
}

\section{Mriam Oluchi Johnson}

Federal University of Agriculture Abeokuta College of Veterinary Medicine

\section{Saganuwan Alhaji Saganuwan (D pharn_saga2006@yahoo.com )}

Federal University of Agriculture Makurdi College of Veterinary Medicine https://orcid.org/0000-00020963-5569

\section{Patrick Azubuike Onyeyili}

Federal University of Agriculture Abeokuta College of Veterinary Medicine

\section{Research Article}

Keywords: Anthracene, Dimethyl sulfoxide, Biomarker, Lung tumour, Rat, Parameter

Posted Date: May 12th, 2021

DOI: https://doi.org/10.21203/rs.3.rs-477123/v1

License: (9) This work is licensed under a Creative Commons Attribution 4.0 International License. Read Full License 


\title{
TUMORIGENIC POTENTIAL OF DIMETHYL SULFOXIDE,
}

\section{ANTHRACENE IN FISH AND ANTHRACENE IN DIMETHYL SULFOXIDE \\ IN RATTUS NORVEGICUS}

\begin{abstract}
AUTHORS: MIRIAM OLUCHI JOHNSON (B.MLS, MSc)
SAGANUWAN ALHAJI SAGANUWAN (DVM, MSc, PhD)

PATRICK AZUBUIKE ONYEYILI (DVM, MSc, PhD)

DEPARTMENT OF VETERINARY PHARMACOLOGY AND TOXICOLOGY, COLLEGE OF VETERINARY MEDICINE, FEDERAL UNIVERSITY OF AGRICULTURE, P.M.B 2373, MAKURDI, BENUE STATE, NIGERIA.
\end{abstract}

CORRESPONDING ADDRESS: pharn saga2006@yahoo.com,

TELEPHONE NUMBER: $\quad+2347039309400$

\begin{abstract}
Anthracene is a polyaromatic hydrocarbon (PAH), present in cigarette smoke and some industries. It may cause tumorigenesis of lungs and other organs. Randomized controlled trial was adopted for the study. Seven out of forty-three rats were used for determination of median lethal dose ( $\left(D_{50}\right)$, whereas thirty-six (36) rats were divided into six groups of six per group. The first group was treated daily with $3 \mathrm{ml} / \mathrm{kg}$ body weight ofwater; the second was treated daily withdimethyl sulfoxide (DMSO) $(30 \mathrm{mg} / \mathrm{kg}$ ), whereas third, fourth and fifth groups were treated with anthracene in DMSO at12.5, 25
\end{abstract}


and $50 \mathrm{mg} / \mathrm{kg}$ body weight, respectively. The sixth group was treated daily withanthracene in fish $(75 \mathrm{mg} / \mathrm{kg})$ for a period of three weeks. Pre-treatment blood samples were collected on day zero (0) and thereafter on day 7,14 and 21 respectively for haematological, cardiorespiratory, tumour kinetic, allometric parameters, as as well as oncogenic biomarkers. Findings revealed that dimethyl sufoxide and anthracene may cause adenocarcinoma of lung characterised by anaemia, neutrophilia or neutropenia, increased cancer antigen-125 (CA-125), carcinoembryonic antigen (CEA), increased heart rate and respiratory rate, superior vena cava oedema and histological changes such as reduced alveolar space, damaged alveolar sacs and infiltration of interseptal space with mononuclear cells. Micro nodules were observed in fibrosed lungs. Hence there is need to assess hazard risk of anthracene in industries and anthracene contaminated environment.

Keyword: Anthracene, Dimethyl sulfoxide, Biomarker, Lung tumour, Rat, Parameter.

\section{INTRODUCTION}

Anthracene also called paranaphthalene or green oil, is a solid polycyclic aromatic hydrocarbon (PAH) of formula $\mathrm{C}_{14} \mathrm{H}_{10}$, consisting of three fused benzene like rings. It is the simplest tricyclic aromatic hydrocarbon from coal tar; melts at $218^{\circ} \mathrm{C}$ and boils at $354^{\circ} \mathrm{C}$ (Lindsey et al., 2014;Aleshinaet al., 2004;Haynes 2014). Although it is insoluble in water, it is soluble in most organic solvents such as carbon disulfide, alcohols, benzene, chloroform and hydronaphthalenes (Aleshinaet al., 2004;Haynes 2014;Douben, 2003), but it is partially soluble in DMSO and Ethyl acetate.A total of 539 PAHs are present in tobacco cigarette and 16 could cause cancer including anthracene 
and naphthalene (USEPA, 1986). They are cytotoxic by causing decreased organ function, damage, hyperplasia, oxidative stress, inflammation and cell proliferation (Andreoliet al., 2003). About 10 - 500ng have been reported for naphthalene in cigarette (Ding et al., 2005). Therefore, PAHs are environmental pollutants that result from incomplete combustion of organic materials present in red and white cigarette. They are $2-8$ ring semi-volatiles (IARC, 2004). Like many other polycyclic aromatic hydrocarbons, anthracene is on the EPA's priority pollutant list. It has been identified in surface and drinking water, ambient air; exhaust emissions, smoke of cigarettes and cigars, in smoked foods, fossils and edible aquatic organisms. Exposure to humans happens mainly through tobacco smoke and ingestion of food contaminated with combustion products. One of the most common ways anthracene enters the body is through breathing contaminated air; this then gets into the lungs. Occupational exposure occurs mainly in a hazardous waste site where PAHs are disposed, working in a plant that makes coal-tar or that uses petroleum or coal or makes or uses wood preservatives.Prolonged exposure causes variety of topical and systemic adverse reactions (Faus, 1991). Human exposure to anthracene has also been associated with headache, nausea, loss of appetite, inflammation of the gastrointestinal tract, slow reactions, and weakness (Volkova, 1983).

Anthracene can vary in appearance from a colorless - white - pale yellow yellow crystal-like solid with a weak aromatic odorbut exhibits a blue fluorescence under ultraviolet radiation $(400-500 \mathrm{~nm}$ peaks) (Lindsey et al., 2014, Larranagaet al., 2016, USCG 1999]. Oxidation of anthracene yields anthraquinone, the parent substance of a large class of dyes and pigments (Aleshinaet al., 2004, Collin et 
al., 2006); hence, used in the production of the red dye alizarin and other dyes (Lindsey et al., 2014), smoke screens, scintillation counter crystals and in organic semiconductor research.It is also used in wood preservatives, insecticides and coating materials. Anthracene is commonly used as a UV tracer in conformal coatings applied to printed wiring boards. The anthracene tracer allows the conformal coating to be inspected under UV light (Zeitler, 2012).

Gas chromatography/mass spectroscopy (GC-MS) could be used to detect PAHs (Vu et al., 2015).GC-MS could detect 4.6ng/cigarette (Zhaet al., 2002). PAHs are present also in foodstuffs and beverages; many of them have structure - tumorigenic relationship, classified as bicyclic or tricyclic depending on their number of cyclic rings. The compounds are further subdivided into all-benzenoid and cyclopentanoidbenzenoid (Rodgman and Perfetti, 2006). Lung cancer volume can be detected and quantified in experimental rodent using contrast agent-based X-ray micro-tomography (Bidolaet al., 2019). Lung tumour could be treated using radioactive rays (Zhang et al., 2016) and chemotherapy (Zhaet al., 2018). In view of this there is need to investigate tumorigenic potential of DMSO, anthracene in fish and anthracene in DMSO with intent to assessing hazard-risk-benefit of anthracene, DMSO and fish in tumours.

\section{MATERIALS AND METHODS}

\section{Experimental animals}

A total of forty-six rats weighing $150 \pm 15 \mathrm{~g}$ were used for the study. The rats were sourced from local breeders in Makurdi, Benue state, Nigeria and kept in plastic cages. They were allowed to acclimatize for a period of two (2) weeks, before the 
commencement of the experiment. They were fed with standard feeds and water was provided ad libitum. The experiments were conducted according to international guiding principles for biomedical research involving animals (C.I.O.M.S 1985), and as recommended by ethical committee of the College of Veterinary Medicine, Federal University of Agriculture, Makurdi.

\section{Acute toxicity study}

The upper limit test was adopted to determine the median lethal dose (LD50) of anthracene and DMSO base on OECD 425 guidelines for testing chemicals, (2000).Three rats each were administered $3000 \mathrm{mg} / \mathrm{kg}$ of DMSO and anthracene in DMSO and observed for a period of 2 weeks. Median lethal dose of anthracene in $10 \%$ acetone and ethanol was determined according to Saganuwan method (2015). One each of male and female rats was administered $250 \mathrm{mg} / \mathrm{kg}$ body weight and observed for 14 days. All the two rats died within the period of two weeks. Thereafter one each of male and female rat was administered $125 \mathrm{mg} / \mathrm{kg}$ body weight and observed for two weeks. All the two rats survived for a period of over two weeks.

\section{Sub-acute toxicity study}

The rats were divided into six groups of six rats each. Group one (I) rats were administered only water, while group (II - V) were treated per Os daily with DMSO (30 $\mathrm{mg} / \mathrm{kg}$ ), anthracene in DMSO 12.5, 25 and $50 \mathrm{mg} / \mathrm{kg}$ body weight respectively, whereas Group (VI) rats weretreated per Os daily with $75 \mathrm{mg} / \mathrm{kg}$ of anthracene in fish, for a period of threeweeks. Pre-treatment blood samples were collected on day zero and thereafter on day 7,14 and 21 respectively for haematological parameters which 
include packed cell volume (PCV), red blood cells (RBC) count, total and differential white blood cells (WBC) count as described by CSLI (2000),Palet al., (2006), CSLI (2007),Praful and DarshanGodkar (2003), Cheesbrough (1998), respectively. Serum was harvested from the whole blood for biochemical analysis of oncogenic biomarkers, CA-125 and CEA using Enzyme Linked Immunosorbent Assay (ELISA) method. The body weights of the rats were measured and recorded prior to the administration of the chemicals and thereafter weekly. The body weights were used to calculate and obtain the physiological parameters and allometric scaling. The rats were euthanized using $100 \mathrm{mg} / \mathrm{kg}$ of pentobarbital. The lungs were collected for histo-pathological examination. The weight, width and breath of the lungs collected were measured for allometry.

\section{Determination of haematological parameters}

\section{Determination of red blood cell (RBC) count}

The RBCs were counted after making a 1:200 dilution with Hayem'sfluid. The improved Neubauer chamber was charged after 2minutes and the RBCs counted using a microscope with x40 magnification (Hayem 1889, Palet al., 2006).

\section{Determination of total white blood cell (WBC) count}

The WBCs were counted after making a 1:20 dilution with Türk's solution.Erythrocytes hemolyze while leukocytes were stained for easy visualization. The improved Neubauer chamber was charged after 30 minutes and the WBCs counted using a microscope with x10 magnification(Cheesbrough, 1998). 


\section{Determination of packed cell volume (PCV)}

The blood sample was drawn into a heparinized capillary tube and centrifuged at 12,000 rpm for 5 minutes, and then the ratio was measured and expressed as a percentage (CLSI, 2000,Cheesbrough, 1998).

\section{Determination of differential white blood cells count}

Thin film made with a drop of blood was stained using a modified Leishman's stain technique.White blood cells were counted after air drying the slides. The slides were then observed under oil immersion objective lens of the microscope. Two hundred cells were then counted and classified. Cells counted were expressed in percentage. (Praful and DarshanGodkar, 2003; CLSI, 2007; Cheesbrough, 1998).

\section{Determination of oncogenic biomarker}

CA-125 and CEA were analysed by enzyme immunoassay and colorimetric method, using commercial Elisa kit (Accu-bind, Monbindlnc.). After the reaction time, the micro wells were read using EMP microplate reader by Shenzhen Emperor Electronic Technology.

\section{Calculation of physiological parameters}

Physiological biomarkers were calculated using the following formulas as described bySchmidt-Nielsen (2004) and Saganuwan(2012).

Body mass ratio (Kcal/day): $3.52 \mathrm{~W}^{0.75}$ (where $\mathrm{W}=$ body weight in gram) 
Total $\mathrm{O}_{2}$ consumption, $\mathrm{V}_{02}\left(\right.$ litre $\mathrm{O}_{2} \mathrm{~h}^{-1}$ ): $0.676 \times \mathrm{Mb}^{0.75}$ (where $\mathrm{Mb}_{\mathrm{b}}=$ body weight in kilogram)

$\mathrm{O}_{2}$ consumption per kilogram (litre $\mathrm{h}^{-1} \mathrm{~kg}^{-1}$ ): $0.676 \times \mathrm{Mb}^{-0.25}$

Heart rate $\left(\mathrm{min}^{-1}\right): 241 \times \mathrm{Mb}^{0.25}$

Lung ventilation rate (litre $\left.\mathrm{h}^{-1}\right): 20.0 \times \mathrm{Mb}^{0.75}$

Lung volume (litre): $0.063 \times \mathrm{Mb}^{1.02}$

Tidal volume (litre): $0.0062 \times \mathrm{Mb}^{1.01}$

Respiration frequency $\left(\mathrm{min}^{-1}\right): 53.5 \times \mathrm{Mb}^{-0.26}$

\section{Determination of tumour kinetic}

Tumour size, tumour volume, tumour weight, tumour doubling time, specific growth rate, tumour cells per day, labelling index, growth factor, tumour doubling time potential and cell loss factor were determined using the method of Saganuwan (2019).

Tumour volume $\left(\mathrm{mm}^{3}\right)=4 / 3 \times \pi \times r^{3}($ where $\pi=3.14159$ and $r=\mathrm{d} / 2)$.

Tumour weight $(\mathrm{mg})=\underline{a \times b^{2}} \quad$ (where $a$ and $b$ are the tumour length and width in 2 millilitre)

Tumour doubling time (day) $=$ One gram of tumour mass $=10^{9}$ cells $=30$ doubling time

Specific growth rate SGR (\%/day) $=\ln _{2} \times 100$ (where DT is tumour doubling time $D T$ and $\ln _{2}=0.6931$ )

Cell cycle per day $($ day $)=\underline{T W X 10^{9}}($ where $T W=$ tumour weight and $T D T=$ tumour 1000 doubling time)

$T D$

Ts

Libelling index $(\%)=T c \overline{(\text { where }} \mathrm{Ts}=$ the duration of the $\mathrm{S}$ phase, $\mathrm{Tc}=$ the duration of the cell cycle)

Growth factor $(\%)=\frac{P}{Q+P} \quad$ (where $P=$ proliferating cells, $Q=$ quiescent cells $)$ 
$T_{\text {pot }}$ (where $T_{\text {pot }}=$ tumour doubling time potential

Cell loss factor $(\%)=\Phi=1-T$ TDand $T D=$ tumour doubling time)

Tumour doubling time potential (day): $\quad T c($ where $G F=$ growth factor, $T c=$ cell GF cycle time)

Tumour cell kill $=\log 10$ cell kill total $=\frac{T-C}{3.32} \times T D\left(\begin{array}{c}\text { no treatment given in this } \\ \text { context })\end{array}\right.$

(where $T=$ median time (days) to reach $1 \mathrm{~g}(1000 \mathrm{mg}), C=$ median time (days) for control tumours and $T D=$ tumour doubling time).

\section{Histopathology}

The tissue samples of the lung obtained from the sacrificed rats were fixed in $10 \%$ formalin. The tissue were dehydrated through graded concentration of ethanol $(70 \%$, $95 \%$ and $100 \%$ ), then cleared in xylene and embedded in paraffin wax. The embedded tissues were stained with Hematoxylene $\left(1^{0}\right.$ dye $)$ and Eosin $\left(2^{0}\right.$ dye $)(H \& E)$ and observed under a light microscope with x100 magnification. The lesions observed were photographed using Vanox T Olympus photographing microscope (Drury et al., 1976).

\section{Statistical analysis}

All data generated during the study were expressed as mean \pm standard error of mean (S.E.M) and analysed statistically by one way analysis of variance (ANOVA). Sifnificant difference was considered at $p \leq 0.05$ using Post Hoc Turkey test. IBM SPSS version 24 computer statistical software was used for the analysis. 


\section{RESULTS}

The limit dose test of $3000 \mathrm{mg} / \mathrm{kg}$ each of anthracene in DMSO and anthracene in DMSO was survived by the rats, thereby projecting $L_{50}$ to be above $3000 \mathrm{mg} / \mathrm{kg}$. Also the LD ${ }_{50}$ of anthracene in $10 \%$ acetone and ethanol was estimated to $180.7 \pm 36.1$ $\mathrm{mg} / \mathrm{kg}$ body weight (Table 1 ). The abnormal signs observed in the male rats administered anthracene in $10 \%$ acetone and ethanol are squeaking, lying in ventral recumbency, nodding of head, partial paralysis, whereas the female rats showed calmness, dullness, high respiration, mild squeaking and partial paralysis before death. Post mortem lesions observed in both male and female rats were congested lungs and heart, empty stomach with normal consistency and areas of necrosis in the liver except for shrunken testis in the male.The signs observed in the rats for the acute toxicity study using DMSO where not as characterized as those for anthracene in $10 \%$ acetone and ethanol but include dullness, death in few minutes, high respiration and weight loss. Post mortem lesions include hydrothorax, focal areas of necrosis on the lungs, congested and micro granulations on the liver, full stomach and empty intestine.Effects of DMSO, anthracene in DMSO and anthracene in fish on body weight, total blood volume, packed cell volume, erythrocyte volume and erythrocyte counts are presented in Table 2. There was significant decrease $(p<0.05)$ in all the parameters at dose level of $50 \mathrm{mg} / \mathrm{kg}$ of anthracene in DMSO on day 7,14 and 21 except for plasma volume on day 21. Anthracene in DMSO at a dose level of $12.5 \mathrm{mg} / \mathrm{kg}$ and $25 \mathrm{mg} / \mathrm{kg}$, DMSO (30 $\mathrm{mg} / \mathrm{kg})$ and anthracene in fish $(75 \mathrm{mg} / \mathrm{kg})$ showed significant increase $(p<0.05)$ in the haematological parameter, except on day 14 and 21 for packed cell volume.Total white blood cells counts and granulocytes increased significantly $(p<0.05)$ on day 21 in 
$50 \mathrm{mg} / \mathrm{kg}$ ofanthracene in DMSO treated rats, whereas monocytes and lymphocytes decreased significantly $(p<0.05)$ in the same group. Similar significant increase or decrease was observed in other treated groups (Table 3) except the group administered water. Cancer antigen $125(\mathrm{CA}-125)$ and carcinoembryonic antigen (CEA) were significantly increased in all the treated groups (Table 4). Body calorie, total oxygen consumption, lung ventilation rate, lung volume and tidal volume were significantly increased in $50 \mathrm{mg} / \mathrm{kg}$ of anthracene in DMSO treated group, whereas respiration frequency and heart rate were significantly decreased $(p<0.05)$ in the same treated group. However, reverse was the case in DMSO and anthracene in DMSO (12.5 and $25 \mathrm{mg} / \mathrm{kg})$ treated groups. Anthracene in fish $(75 \mathrm{mg} / \mathrm{kg})$ treated group was not affected significantly (Table 5).The tumorigenic potential of anthracene on haematological parameters shows significant increase in the group administered water, DMSO and anthracene in DMSO 12.5 and $25 \mathrm{mg} / \mathrm{kg}$ except the $50 \mathrm{mg} / \mathrm{kg}$ treated group. However the group treated with $75 \mathrm{mg} / \mathrm{kg}$ body weight had the parameters restored to normal, but RBCs decreased in all the groups treated with DMSO, anthracene in DMSO and anthracene in fish $(p<0.05)$ (Table 6). There was significant difference in leucocytes counts in all the treated groups $(p<0.05)($ Table). The euthanized rats were observed for post mortem lesions. Before euthanasia, the rats administered $50 \mathrm{mg} / \mathrm{kg}$ had alopecia from 14day after administration, Increased respiration and lethargy.After euthanasia, stomach and intestine were empty. Lungs were paleand enlarged weighing an average of $2.1 \mathrm{~g}$, measuring $3.6 \times 1.4 \mathrm{~cm}$ with macro nodular lesions measuring $3.0 \times$ $2.1 \mathrm{~mm}$. Areas of degeneration were observed on the lungs of more than $50 \%$ of the rat population. Whereas, in the rats administered DMSO $(30 \mathrm{mg} / \mathrm{kg})$. Hydrothorax was 
observed in about all the rat population, the lungs were pale and shrunken. Stomach was full but intestine was empty. The heart was congested.

\section{DISCUSSION}

Induction of lung tumour associated with its biomarkers within 3 weeks using DMSO and anthracene in DMSO agrees with the report indicating that tumorigenesis of the lung can take place within 21 days (Netoet al., 2008). Decreased calorie, total oxygen consumption, oxygen consumption per kilogram, lung ventilation rate and tidal volume which are suggestive of dyspnea and hypoxemia observed in this study, agrees with the report recommending oxygen for lung cancer patients (Tiepet al., 2013). However, oxygen use is not associated with survival in patients with advanced lung carcinoma (Igarashi et al., 2020), but, new adjuvant chemotherapy could cause linear peak of volume of oxygen (Vo2) in cancer patients (Fresardet al., 2016). Conversely, peak oxygen consumption is a predictor of lung cancer resected patient survival (Lindenmanet al., 2020). Therefore peak $\mathrm{Vo}_{2}$ is an independent predictor of survival in non-small cell lung cancer (Jones et al., 2010). Tidal volume is a predictor of pulmonary complication in lung cancer surgery (Licker et al., 2011). Increased and decreased heart rate observed in $50 \mathrm{mg} / \mathrm{kg}$ and $25 \mathrm{mg} / \mathrm{kg}$ anthracene in DMSO treated groups respectively agree with the report of Franklin et al (2016) indicating that heart rate is a predictor of survival in non-small cell lung cancer and as such represent a therapeutic target as observed in anthracene in fish $(75 \mathrm{mg} / \mathrm{kg})$ treated group. Univariant analysis reveals that heart rate variability parameters are a predictor of poor survival in advanced non-small cell lung cancer (Kim et al., 2015) and brain metastasis (Wang et al., 2013). However, elevated heart rate could be a risk factor for cardiopulmonary complications 
after resection of lung cancer (Fu et al., 2018), but asymptomatic sinus bradycardia could be caused by crizotinib in non-small cell lung cancer patients (Ouet al., 2011), which has 5 year survival in stage I of $>21 \mathrm{~mm}$ (Okada et al., 2004). Staging of primary carcinoma of the lung acquires invasion of the elastic layer of viscera pleura (Khan and Lynch, 2021). Adenocarcinoma, squamous cell carcinoma and large cell carcinoma are the three main types of non-small cell lung cancer that affect $80-85 \%$ whereas small cell lung cancer which is neuro-endocrine affect $15-20 \%$ lung cancer patients (PerezMoreno et al., 2012).

The increased cancer antigen $125(\mathrm{CA}-125)$ and carcinoembryonic antigen (CEA) observed in all the treated groups confirm tumorigenic potential of DMSO and anthracene in the present study. CA-125 and CEA have been reported to be biomarkers of non-small cell lung cancer, lung tumour, lung adenocarcinoma, liver and ocular metastases secondary to lung cancer (Salficet al., 2000; Diezet al., 1991; Bucheri and Ferrigno, 2002; Yang et al., 2018; Li et al., 2020; Zanget al., 2019; Isakssonet al., 2017; Wang et al., 2020) as indicated by gross pathology and histopathology of the lung lesions. The two antibodies could be used also for lung cancer screening, liver and ocular metastases secondary to lung cancer and as a predictor of resectable lung adenocarcinoma recurrence (Yang et al., 2018; Wang et al., 2020; Li et al., 2020; Isakssonet al., 2017).Therefore, oncologist should take cognisance of clinical relevance of anaemia in lung cancer (Pirkeret al., 2003), because observed anaemia could be exacerbated by some anticancer drugs (Crawford et al., 2006). Decreased red blood cells distribution width (RDW) is a strong index of survival in lung cancer patients (Kos et al., 2016). The observed neutrophilia and neutropenia in the treated group agrees 
with the report indicating that neutrophils could be used as biomarker of cancer detection. Tumour- associated neutrophilia (TANs) could be controlled by tumour microenvironment and aid in tumour progression. So TANs could be detrimental and beneficial (Uribe-Querol and Rosales, 2015). However, neutrophilia is a negative prognostic factor in lung cancer patients, but other white blood cells do not affect patient survival (Kohutek and Bystricky, 2019). Nevertheless, leucocyte count is independent on physical activity in lung cancer patients (Sprague et al., 2008), as shown by increased heart rate and respiration rate in the present study. Suggesting that leucocytosis is an important biomarker for increased lung cancer risk (Wong et al., 2019). Hence, tumour-related leucocytosis is related importantly to non- small cell carcinoma and it is an ominous prognostic sign (Kasagaet al., 2001). The swelling of the right vena cava of all the rats administered $50 \mathrm{mg} / \mathrm{kg}$ of anthracene in DMSO is similar to superior vena cava syndrome in cancer, thoracic malignancies, thyroid metastasis and non-small cell lung cancer, as position is dependent onperiorbital oedema, in a patient with advanced lung cancer that can respond to chemoradiation, and can be treated with implantation of intravascular stent and chemotherapy, angioplasm, anticoagulation, raising the head, and its proposal classification maybe based on algorithm of management (Coiffardet al., 2014, Kinnard 2012; Lepperet al., 2011; Pose et al., 2017; Brzeniaket al., 2017; Rajagopal and Simala, 2014; Ngugenet al ., 2018; Hinlonet al., 2018; Chong et al., 2005; Cirinoet al., 2005; Yu et al., 2008). Induction of lung tumour as shown by histological slides is via histochemical enzymes (Suzuki, 1966).

Tumor makers are quite diagnostic, prognostic and for monitoring cancer initiation and progression (Faulkner and Meldrum, 2012). Therefore tumor makers 
including CEA are used for population screening, diagnosis, tumor detection and staping. They are proteins, antigens, glycoproteins, hormones and enzymes. Monoclonal antibody is commonly used for identification of specific markers in urine, blood and tissue samples (Kumar et al., 2014). CA-125 of molecular weight 200KD identifies ovarian carcinoma and it is prognostic after chemotherapy, whereas CEA which comprises $45-60 \%$ carbohydrate $(180 \mathrm{KDa})$ is used for monitoring gastrointestinal colorectal, lung and mammary tumors (Kumar et al., 2014). High CEA levels have been observed in epithelial tumors and $40-80 \%$ of non-small cell lung cancer with higher sensitivity in advanced cancer (Fletcher, 1986; Hansen, 1991). Hence numerous biomarkers are required for detection of lung tumor at early stage (Ferrigno and Buccheri, 1995). Interstitial fibrosis, emphysema and entrapped pneumocytes show predominance of squamous cell carcinoma (Hayashi et al., 2013). Suggesting that natural products may be used to fight both phenotypic and genetic components of oncogenesis (Bertrand et al., 2014) together with analogous patient-derived immune cell vaccines, peptide vaccine and tumor antigen-expressing recombinant vaccine (Thomas and Prendergast, 2016). Hydration and nutrition provide benefit for cancer patients (Arendset al., 2017). Overweight and obesity increase the risk of colorectal, oesophageal, breast, endometrial and kidney cancers. Fruits and vegetables reduce the risk of oesophageal, colorectal, stomach and oral cavity cancers. The ameliorative effects of fish in the present study disagrees with the report indicating that China-style salted fish increases the risk of nasopharyngeal cancer, as red meat increases the risk by colorectal cancer (Key et al., 2004). However low protein diet is associated with low incidence of cancer risk and mortality, hence it can be used in treatment and prevention 
of cancer (Yin et al., 2021) as done in the present study. Fish oil is a promising intervention for lung cancer (Kiss, 2016). Vitamin E increased incidence of lung cancer (Slativeet al., 2008). Defensive micronutrients, carcinogens and mutagens may adapt cancer development in genetically susceptible individuals (Patel et al., 2018). Early nutritional intervention improves health status in cancer patients (Richards et al., 2020).

Tumor antigens could serve as basis for immunotherapy in the clinical oncology (Ribaset al., 2013). Cancer genomes could be rearranged with changes in copy number losses and gains, that deregulate tumor suppressors and oncogenes, which may acquire mutation and fusion genes may be created by rearrangement of genomes. Changes in chromatin structure and methylation could contribute to cancer development. Driver mutations contribute to tumorigenesis whereas passenger mutations are acquired during cancer evolution, but do not contribute to carcinogenesis (Lach and Adams, 2013). Changes observed in cardiorespiratory parameters agree with the report recommending physiotherapy for management of lung cancer (Granger, 2016). More so gene-specific cancer therapy is a function of oncogenes and tumor suppressor genes (Vogt, 1993). Methods used for stimulation of effective and lunglasting immune responses have been part of focus in cancer vaccinology and immunology (Apostolopoulos, 2019), as cancer vaccine prevents cancer causing viruses, prevents oncogenesis and treats cancer (Arvindet al., 2010). Binding of oncogenes to DNA has been responsible for mutagenesis and carcinogenesis (Stark, 1980). Dendritic cells are vital to generation by immune responses, therefore represents vector and target for vaccination in cancer immunology (Paluckaet al., 2011). 
Anthracene has a characteristic environmental behaviour; at $20^{\circ} \mathrm{C}$, it is solid with very low volatility and low solubility. It volatilize moderately once dissolved and adsorbs very strongly to organic matter. When present in soil, anthracene will volatilize and solubilize very slowly. Once dissolved, it will either enter the groundwater table or migrate towards a waterway, where it will be diluted before partially volatilizing. Fragments of anthracene in the waterways will deposit at the bottom and will slowly dissolve. Even after the source is removed, adsorbed anthracene will take a very long time to disappear, thereby, liberating contamination in either the gaseous or dissolved state with relatively small size fumes. Information on the toxicity of anthracene exposure in humans is very limited. Evidence indicates that anthracene is absorbed following oral and dermal exposure. Targets for anthracene toxicity are the skin, hematopoietic system, lymphoid system, and gastrointestinal tract. Adverse dermatologic effects have been observed in humans and animals in conjunction with acute and subchronic exposure to anthracene. In humans, anthracene may cause acute dermatitis with symptoms of burning, itching, and edema. Prolonged dermal exposure produces pigmentation, cornification of skin surface layers, and telangiectasis (Volkova, 1983). There are little or no data on the tumorigenic effects of anthracene on the lungs following oral administration, although a large body of literature exists on the toxicity of PAHs, data for anthracene are limited. Carcinogenicity bioassays with anthracene generally gave negative results except in the present study. The U.S. Environmental Protection Agency has indicated that not enough information exists to classify anthracene as a cancer causing substance (USEPA, 1986). 


\section{CONCLUSION}

The LD50 of anthracene in DMSO was estimated to be above $3000 \mathrm{mg} / \mathrm{kg}$ whereas that of anthracene in $10 \%$ acetone and alcohol was estimated at $151.4-223.6 \mathrm{mg} / \mathrm{kg}$ body weight respectively. Anthracene in DMSO at $50 \mathrm{mg} / \mathrm{kg}$ caused significant increased tumour parameters that were ameliorated by anthracene in fish $(75 \mathrm{mg} / \mathrm{kg}$ ). the increased parameters were principally of lung tumour. Macro-nodular lesions of 1-3 mm were also observed in the lung of affected rats as confirmed by histopathological lesions. Hence, acute oral ingestion of anthracene could pose risk of lung tumour. Haematological, cardio-respiratory, tumour kinetic and cancer biomarkers could be used for detection of anthracene induced lung tumour in rats.

\section{ACKNOWLEDGEMENTS}

The authors thank sincerely MrUpev Vincent, Mr Daniel Achanya and Mr David Orbunde of Physiology and Biochemistry laboratory and Department of Veterinary Pharmacology and Toxicology, Federal University of Agriculture, Makurdi, for their contributions in various capacities.

\section{AUTHORS CONTRIBUTIONS}

SaganuwamAlhajiSaganuwan and Patrick A. Onyeyili designed the study, whereas

Miriam O. Johnson and Saganuwan A. Saganuwan carried out the study and statistical analysis. All the contributors proofread the manuscript. 


\section{CONFLICT OF INTEREST}

The authors have no conflict of interest to declare.

\section{ETHICAL CLEARANCE}

Ethical clearance was obtained from College of Veterinary Medicine, Federal University of Agriculture, Makurdi. 


\section{REFERENCES}

Aleshina AN, Lee JY, Chu SW, Kim JS and Park YW, Appl. Phys. Lett. 84 (2004) 5383-5385.

Andreoli $C$, Gigante $D$, Nunziata $A$. A review of in vitro methods to assess the biological activity of tobacco smoke with the aim of reducing the toxicity of the smoke. ToxicollnVitr 2003; 17(5-6): 587-594.

Anker MS, Ebner N, Hildebrandt B, Springer J, Sinn M, Riess H, Anker SD, Landmesser U, Haverkamp $W$, Von Hachlong $S$. Resting heart rate is an independent predictor of death in patients with colorectal, pancreatic and non-small cell lung cancer: results of a prospective cardiovascular long-term study. Eur $J$ Heart fail 2016; 18: 1524-1534.

Aposlotopoulos V. Cancer vaccines: research and applications. Cancer 2019;11:1-5.

Arends J, Bachmann P, Baracos V, Barthelem N, Bertz H, Bozzetti F, Fearon K, Hutterer E, Isenring E, Kassa S, Krznaric Z, Laird B, Larsson M, Laviano A, Muhlebach S, Nuscantoli M, Oldervoll L, Ravasio P, Sokeim $T$, Strasser $F$, de vanderSchueren M, Preiser JC. ESPEN guidelines on nutrition in cancer patients. ClinNutr 2017; 36:11-48.

Arvind BRS, Kiran KK, Sidhar RG, Anuradha C. Cancer vaccine: a review. J OrofacSci 2010; 2(3): 77-82.

Bertrand N, Wu J, Xu X, Kamaly N, Favokhzad OC. Cancer nanotechnology: The impact of passive and active targeting in the era of modern cancer biology. Adv Ding Deliv Rev 2014; 66:2-25.

BidolaP,Silva JMS, Achterhold K, Munkhbaater E, Jost PJ, Manhavidt A-L, Taphorn K, Zdiva M-C, Pferiffer $F$, Herzen J. A step towards valid detection and quantification of lung cancer volume in experimental mice with contrast agent based x-ray microtomography. Sci Rep 2019; 9:1-10.

Brown, BM. Haematology principles and procedures, $2^{\text {nd }}$ ed. 1976. Lea and Febiber Philadelphia, pp 5681.

Brzemak C, Oronsky B, Carter CA, Thilagar B, Caroen S, Zemen K, Superior vena cava syndrome in a patient with small-cell lung cancer: a case report. Case Rep Onal2017;10:252-257.

Buccheri G, Ferrigno D. Lung tumor markers in oncology practice: a study of TPA and CA-125. Br J Oncol 2002; 87:1112-1118.

C.I.O.MS (Council for international organization of medical science).International guiding principles for biomedical research involving animals.(1985). Available at http://http//www.cioms.ch/frame_1985_textof_guidelines.htm.

Cheesbrough M. District Laboratory practice in tropical countries. 2009; $2^{\text {nd }}$ ed. Cambridge university press.

Chong J-T, Wu J-C, Chang $C-H$, Hsueh E-J. Non-small cell lung cancer with superior vena cava syndrome effectively treated with implantation of intravascular stent and chemotherapy- a case report and review of the literature. ActaCardiol Sin 2005; 21:4p-53.

Cirimo LMI, Codho RF, Da Rocha ID, Balista BPSN. Treatment of superior vena cava syndrome.J Bras Piramol 2005; 31(6): 540-550.

CLSI. Procedure for Determining Packed Cell Volume by the Microhematocrit Method; Approved Standard-Third Edition. CLSI document H07-A3. Wayne, PA: Clinical and Laboratory Standards Institute; 2000. 
CLSI. Reference Leukocyte (WBC) Differential Count (Proportional) and Evaluation of Instrumental Methods; Approved Standard-Second Edition. CLSI document H20-A2. Wayne, PA: Clinical and Laboratory Standards Institute; 2007.

Coiffard B, Elharrar X, Vandemoortele T, Laroumagne S, Dutan H, Astoal P. The hypermetabolic mushroom: Superior vena cava syndrome. Am J Radiol 2014; 127(5): 395-397.

Collin G, Höke H, Talbiersky J. "Anthracene" in Ullmann's Encyclopedia of Industrial Chemistry, WileyVCH, Weinheim. 2006. doi:10.1002/14356007.a02_343.pub

Crawford J, Kosmidis PA, Hirsch FR, Langer CJ. Targeting anaemia in patients with lung cancer. T Thoracic Oncol 2006; 1(7): 716-725

Diez M, Cerdan FJ, Ortega MD, Torres A, Picardo A, Balibrea JL. Evaluation of serum CA-125 as a tumor marker in non-small cell lung cancer. Cancer 1991; 67(1): 150-154.

Ding YS, Trommel JS, Yan XJ, Ashley YD, Watson $\mathrm{CH}$. Determination of polycyclic aromatic hydrocarbon in mainstream smoke from domestic cigarettes. Environ SciTechnol 2005; 39127: 471-478

Douben PET. Bioaccumulation of PAHs in Marine invertebrate. In: PAHs: An Ecological perspective (Meador Jed) John Weley and sons, Chichester, UK 2003:407

Drury RA, Wallington EA, Cancerson R. Carleton's Histopathology Techniques. $4^{\text {th }}$ ed. Eds 1976.London: Oxford University press, pp 21- 70.

Faulkner D, Meldrum C. Tumor markers. AutrPrescrib 35(4):125-128.

Faust, Rosmarie A. Chemical Hazard Evaluation Group. Toxicity Summary for Anthracene.Oak Ridge National Laboratory. Oak Ridge, TN:1991.

Ferrigno D, Buccheri G. Clinical applications of serum markers for lung cancer. Respir Med 1995; 89:587597.

Flectcher RH. Carcinoembryonic antigen. Ann intern Med 1986; 104: 66-73.

Fresard I, Licker M, Adler D, Lovis A, Robert J, Karenovics W, Diaper J, Jansens JP, Triponez F, Lador F, Rodiat T, Espiriosa V, Bhalia C, Kayser B, Bridevaux PO. Preoperative oxygen uptake in lung cancer subjects with neoadjuvant chemotherapy- a cross-sectional study. Respir care 2016; 61(8): 1059-1066.

Fu D, Wu C, Li Xi Chen J. Elevated preoperative heart rate associated with increased risk of cardiopulmonary complications after resection for lung cancer. BNC Anesthesia 2018; 18 (94). 1-6.

Grangers CL. Physiotherapy management of lung cancer. J Physiother 2016; 62:60-67.

Grawford J, Kosmidis PA, Hirsch FR, Larger CJ.Targeting anemia in patients with lung cancer.J Thoracic Onal 2006; 1(7): 716-725.

Hansen M. Serum tumor markers in lung cancer.Scand J Clin lab Invest Suppl 1991;206:93-101.

Hayashi T, Sano H, Egashira R, Tabatak, Tanaka T, Nakayama T, Kashima T, Hori T, Nunomura S, Fukuoka J. Difference of morphology and immunophenotype between central and pheripheral squamous cell carcinoma of the lung. Biomed Res Int2003: ID 157838

Hayem, G. Du Sang et des AltirationsAnatomiques, Paris. 1889.

Haynes, W.M. (ed.). CRC Handbook of Chemistry and Physics. 95th Edition. CRC Press LLC, Boca Rato n: FL 2014-2015, p. 3-28, p. 5. 157 
Hinton J, Cerra-FrancoA, Shive K, Shea L, Aaron V, Billows G, Al-Hadder A, Loustenschlaeger T. Superior vena cava syndrome in a patient with locally advanced lung cancer with good response to definitive Chemoradiation: a case report. Med care Rep 2018;12(301).1-6.

IARC.Tobacco smoke and involuntary smoking. Monographs on the Evaluation of Carcinogemic Risk to Humans 2004; 83: 33-1187

Igarashi $H$, Fukushi $M$, Nago $N$. Oxygen use and survival in patients with advanced cancer and low oxygen saturation in home care: a preliminary retrospective cohort study. BMC palliate care 2020; 19(3):1-10.

Isaksson S, Jonsson P, Monsef N, Brunstrom H, Bendahi P-O, Jonsson M, Staaf J, Planck M. CA19-9 and CA 125 as potential predictors of disease recurrence in resectable lung adenocarcinoma. Plos one 12(10): 113.

Jones LW, Watson D, Herndon JE, Eves ND, Haithcock BE, Loewen G, Kohman L. Peak oxygen consumption and long term all-cause mortality in non-small cell lung cancer. Cancer 2010;116: 48254832.

Kasuga I, Makino S, Kiyokawa H, Katoh H, Ebihara Y, Ohyashiki K. Tumor-related leukocytosis as linked with poor prognosis in patient with lung carcinoma. Cancer 2001; 92(9): 2399-2405.

Key J, Schatzkin A, Willett WC, Allen NE. Spencer EA, Travis RC. Diet, nutrition and the preventionof cancer. Public Health Nutr 2004; 7(1A): 187-200.

Khan YS, Lynch DT.Histology, lung.Startpearls - NCBI book shelf 2021: 1 - 12

Kim K, Chae J, Lee S. The role of heart rate variability in advanced non-small cell lung cancer patients.J Pathative Care 2015, 3112).103-108.

Kinnard E. Superior vena cava syndrome in the cancer patient a case study.J AdvPractOncol 2012; 3: 385$38 D$.

Kiss $N$. Nutrition support and dietary interventions for patients with lung cancer: current insights. Lung canc: Target Ther 2016; 7:1-9.

Kohutek $F$, Bystricky $B$. Leukocytosis as a negative prognostic factor in patients with lung cancer: which sub population of leukocytes is responsible? Ann Onal 2019 (5): 797-815.

Kos N, Hocazade C, Kos FT, Unai D, Karakas E, Dogan M, Uncu HG, Ogdemir N, Zengin N. Evaluation of the effects of red blood cell distribution width on survival in lung cancer patients. ContempOnal (Pozn) 2016; 20 (2): 153-157.

Kumar K, Jain $P$, Sinha A, Singh KK, Sharma HP.Clinical significance of tumor markers. Ann $J$ PhytomedclinTher 2014; 2(8): 1005-1015.

Lach RP, Adams DJ.Cancer genetics. Brenner's Encychopedia of Genetics, Volume 1,2 ${ }^{\text {nd }}$ ed., 2003:416.

Larranaga, M.D., Lewis, R.J. Sr., Lewis, R.A.; Hawley's Condensed Chemical Dictionary 16th Edition. Joh $n$ Wiley \& Sons, Inc. Hoboken, NJ 2016., p. 98

Leishman W (1901). "Note on a Simple and Rapid Method of Producing Romanowsky Staining in Malarial and other Blood Films". Br Med J. 2 (2125): 757-758. Doi:10.1136/bmj.2.2125.757. PMC 2507168.PMID 20759810

Lepper PM, Ot SR, Hoppe H, Schumann C, Stammberger II, Bugalho A, Frese S, Schmiiking M, Blumstein NM, Diehm N, Bals R, Hamacher J, Superior vena cava syndrome in thoracic malignancies. Repir care 2011; 56(5): 653-666. 
Li B, Yuan Q, Zou Y-T, Su T, Lin Q, Zhang Y-Q, Shi W-Q, Liang R-B, Ge Q-M, Li Q-Y, Shao Y. CA-125, CA153, and CYFRA $21-1$ as chemical indicators in male lung cancer with ocular metastasis. $J$ Cancer 2020; 11 : 2730-2736.

LickerM, Schnyder J-M, Frey J-G, Diaper J, Cartler V, Inan C, Robert J, Bridevaux P-O, Tschopp J-M. Impact of aerobic exercise capacity and procedure-related factors in lung cancer surgery. EUR Respir $J$ 2011; 37:1189-1198.

Lindenmann J, Emk-Neuboeck N, Fediuk M, Maier A, Kovacs G, Batic M, Smolle J, Smolle-Juettner FN. Preoperative peak oxygen consumption: a predictor of survival in resected lung. Cancers 2020;12: 1-12.

Lindsey, Jonathan; et al. "Anthracene". PhotochemCAD.Retrieved 20 February 2014.

Monica Cheesbrough, District Laboratory practice in Tropical countries part 2 Cambridge University press 1998, Page 309-317, 320-326

Neto AG, Simad AFL, Miranda SP, Mourad LTC, Begerra NP, de Almeda. PRC, Ribeiro RA. Experimental rat lung tumor model with intrabronchial tumor cell implantation. Act cirBrasil 2008;23(i): 84-92.

Nguyen AL, Belderbos H, Van Harten JG, Wijne L. Superior vena cava syndrome presenting as position dependent periorbital oedema. BMC case Rep 2018; Doi:10.11361ber-2018-225220.

OECD (2000) Guidance document on acute oral toxicity. Environmental health and safety monograph series on testing and assessment No. 24.

Okada M, Nishio W, Sakamolo T. Uchino K, Yuki T, Nakagawa A, Tsubota N. Effect of tumour size on prognosis in patients with non-small cell lung cancer: the role of segmatechtomy as a type of lesser resection. Thoracic CardiorascSurg 2005, 129(1): 87 - 93.

Ou S-HI, Azada N, Dy J, Stiber JA. Asymptomatic profound sinus bradycardia (heart rate $\leq 45$ ) in non-small cell lung cancer patients treated with Crizotinib. J Thoracic Oncol 2011; 6/12; 2135-2137.

Pal GK, Pal, Pravati. Textbook Of Practical Physiology $-2^{\text {nd }}$ Ed. Orient Blackswan. Human physiology. 2006. 456 pages. Page 45

Palucka K, Ueno H, Banchereau J. Recent developments in cancer vaccines. J Immunol 2011; 186:13251331.

Patel A, Pathak Y, Patel J, Sutariya V. Role of Nutritional factors in pathogenesis of cancer. Food QualSci f 2018; 2:27-36.

Perez-Moreno P, Brambilla E, Thomas R, Soria JC.Squamous cell carcinoma of the lung: molecular subtypes and therapeutic opportunities. Clin Cancer Res 2012; 18(9): 2443.

Pose VV, Alaris MPF, Naveira AB, Gonzalez OLS, Noya JF, Herranz UA, Lopez RL. Unusual case of superior vena cava syndrome caused by intravascular thyroid metastasis case. Rep Oncol Med 2017: ID 8675239.

Praful B.G, Darshan P.G. Textbook of Medical Laboratory Technology. Bhalani Publishing House.ISBN 8185578583, 9788185578583. (2003). 1094 pages

Priker R, Wiesenberger K, Pohl G, Minar W. Anaemia in lung cancer. Clin lung cancer 2003; 5 (2): 90-97.

Rajagopal A, Simala J. Superior vena cava syndrome development in non-small cell lung cancer. Lung Canc 2014; 145(3):1-2.

Ribas A, Butterfield LH, Glaspy JA, Economou JS. Current development in cancer vaccines and cellular immunotherapy. J Chin Onal 2003; 21(12):2415-2432. 
Richards J, Arensberg MB, Thomas S, Kerr KW, Hegazi R, Baseasch M. Impact of early incorporation of nutrition interventions as component of cancer therapy in adults: a review. Nutrient 2020; 12:1-16.

Rodgman A, Perfetti A. The composition of cigarette smoke: a catalogue of the polycyclic aromatic hydrocarbons. BeitrTabakInt 2006; 22(i): DOI: 10-2478/ctr-2013-0817..

Saganuwam SA.Arithmetric Geometric-Harmonic (AGH) method of rough estimation of median lethal dose using up-and=down procedure. Drug MatabToxicn 2015. 6(2): 1-3

Saganuwam SA. Mathematical determination of some oncological parameter anf their therapeutic implications in dogs. Comp Clinpathol 2019; 28(4): 1025-1030

Saganuwam SA. Principles of Pharmacological calculations, $1^{\text {st }} \mathrm{ed}$, Ahmadu Bello University printing press, Nigeria. 2012:529

Saganuwam SA. The use of body surface area for determination of age, body weight, urine creatinine, serum creatinine urine volume and creatinine clearance: the reliable canonical method of assessing renotoxicity in animals. Comp ClinPathol 2018; 27:1531-1536

Salgia R, Harpole D, Herndir JE. Role of serum tumor markers: CA-125 and CEA in non-small cell lung cancer. Anticancer Res 21(2B): 1241-1246.

Schmidt-Nielsen, K. Desert animals: physiological problrms of heat and water. Claredon press, Oxford (1964).

Singh S, Vishal, Vashishth A, Ali A. Polycyclic aromatic hydrocarbon in cigarette smoke. J Punjab Acad Sci. 2008-2009;5-6(182):134-136.

Slative CG, Littman AJ, Hu DH, Satia JA, White E. Long term use of supplemental multivitamins, Vitamin C, E and plate doses not reduce the risk of lung cancer. Ann J RaspirCrit Care Med. 2008; 177: 524-530.

Sprague BL, Trentham-Diez A, Klern BEK, Klern R, Cruickshenks KJ, Lee KE, Hampton JM. Physical activity, white blood cell count, and lung cancer risk in a prospective cohort study. Cancer Epidemiol Biomarkers prev 2008; 19(10): 2714-2722.

Stark A.A Nutagenicity and carcinogencity or mycotoxins: DNA binding as a possible mode of action. Ann Rev Microbiol 1980; 34:235-262.

Suzuki T. Histochemical studies on enzymes in lung tumors. Gann 1966; 57:169-184.

Thomas S, Prendergast G.C. Cancer vaccines: A brief review.Thomas S(ed) Vaccine Design: Methods and protocols, Springer New York 2016:755-761.

Tiep B, Carter R, Zachariah F, Williams AC, Horak D, Barneth M, Dunham R. Oxygen for the end-of-life lung cancer care: managing dyspnea and hypoxemia. Expert Rev RespirMed 2013; 2157: 479-490.

U.S. Coast Guard. 1999. Chemical Hazard Response Information System (CHRIS) -

Hazardous Chemical Data. Commandant Instruction 16465.12C. Washington, D.C.: U.S. GovernmentPrin ting Office.

Unbe-QuerolE, Rosales C. Neutrophils in cancer: two sides of the same lungs. J (mmum) Res2015: ID 983698.

Uribe-Querol E, Rosales C. Neutrophils in cancer: two sides of the same coin. J Immunol Res 2015: ID 983698

U.S. Environmental Protection Agency guidelines for carcinogen risk assessment, 1986. 
Vogt PK. Cancer genes. Wet J Med 1993; 158: 273-278.

Volkova NI. Anthracene and derivatives. In: Encyclopaedia of Occupational Health and Safety, Vol. 1. L. Parmeggiani, Ed. 1983. International Labour Office, Geneva, pp. 162-163.

Vu AT, Taylor KM, Holman MR, Ding YS, Hearn B, Watson $\mathrm{CH}$. Polycyclic aromatic hydrocarbons in the mainstream smoke of popular U.S cigarettes. Chem Res Toxcol 2015; 28(8): 1616-1626.

Wang EF, Peng S-J, Liv R-Q, Yu Y-J, Ge Q-M, Liang R-B, Li Q-Y, Li B, Shao Y. The combination of CA-125 and NSE is useful for predicting Liver metastasis of lung cancer. Dis marker 2020: ID 8850873.

Wang $Y-M$, Wu $H-T$, Huang E-Y, Kou YR, Hsen S-S. Heart-rate variability is associated with survival in patients with brain metastasis; a preliminary report. Biomed Res Fnt 2003, ID 503421.

Wong JYY, Bassig BA, Loftfield E, Hu N, Freedman ND, Ji B, Elliot P, Silverman DT, Chanock SJ, Rothman N, Lan Q. White blood cell count and risk of incident lung cancer in the UK Biobank. JNCL Cancer Spect 2020; 4(2): 1-9.

Yang $Q$, Zhang $P$, Wu $R$, Lu K, Zhon $H$. Identifying the best marker combination in CEA, CA-125, CY 211, NSE and SCC for lung cancer screening by combining. ROC curve and logistic regression analysis: Is it feasible? Dis marker 2018; ID 2082840.

Yin J, Ren W, Huang X, Li T, Yin Y. Protein restriction and cancer. Cancer 2021.

Yu, JB, Wilson LD, Ditterbeck FC.Superior vena cava syndrome- a proposed classification system and algorithm for management.J Thoracic Onal 2008;3(8): 811-814.

Zang R, Li Y, Jin R, Wang Xi, Lei Y, Che Y, Lu Z, Mao S, Hwang J, Liu C, Zheng S, Zhon F, Wu Q, Gao 8, Sun $\mathrm{N}, \mathrm{He} \mathrm{J}$. Enhancement of diagnostic performance in lung cancers by combining CEA and CA-125 with autoantibodies detection. Onco immunology 2019; 6(10): e1625689.

Zeitler, Alex (2012-06-27) Conformal Coating 101: General Overview, Process Development, and Control Methods. BTW, Inc

Zha Q, Qian NX, Moldoveanu SC. Analysis of polycyclic aromatic hydrocarbons in the particulate phase of cigarette smoke using a gas chromatographic - high - resolution mass spectrometric technique. $J$ Chromotosr Sci. 2002; 40;403-408.

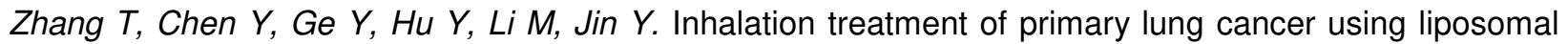
curcumin dry powder inhalers. Act pharmaceut Sin B 2018; (3): 440-448.

Zhang Z, Wodzak M, Belzile O, Zhou H, Sishc B, Yan H, Slojadinovic S, Mason RP, Brekken RA, Chopra $R$, Story $M D$, Timmerman $R$, Saha $D$. Effective rat lung tumor model for stereotactic body radiation therapy.Radiat, Rest 2016; 185: 616-622. 


\section{Figures}

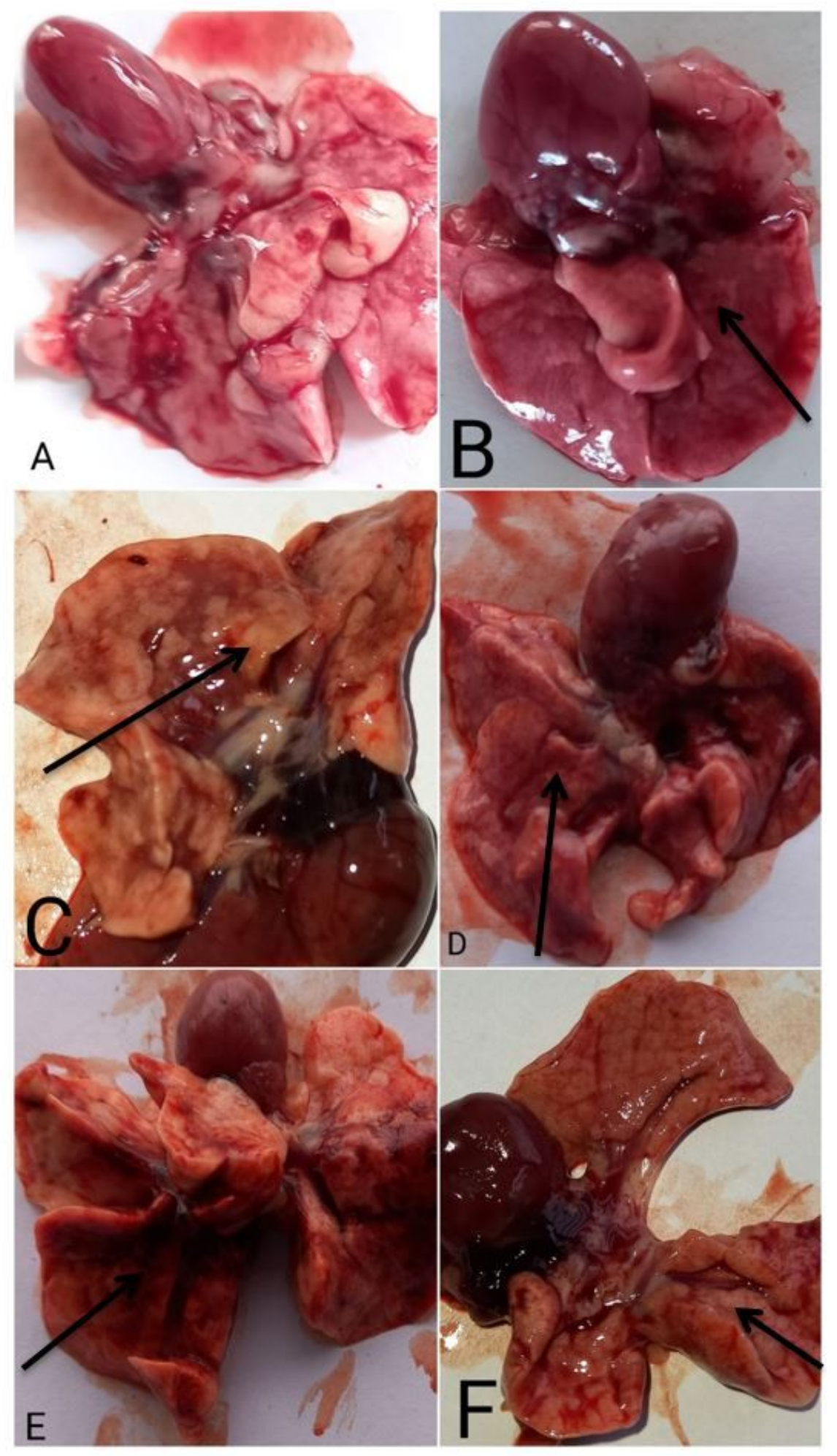

\section{Figure 1}

Shows lung and heart of rat administered water (A), anthracene in fish; $75 \mathrm{mg} / \mathrm{kg}(\mathrm{B})$, anthracene in DMSO; $50 \mathrm{mg} / \mathrm{kg}, 25 \mathrm{mg} / \mathrm{kg}, 12.5 \mathrm{mg} / \mathrm{kg}$ (C, D and E respectively), and DMSO; $30 \mathrm{mg} / \mathrm{kg}$ (F) for a period of 21 days. Arrows show affected tumour lesions. 

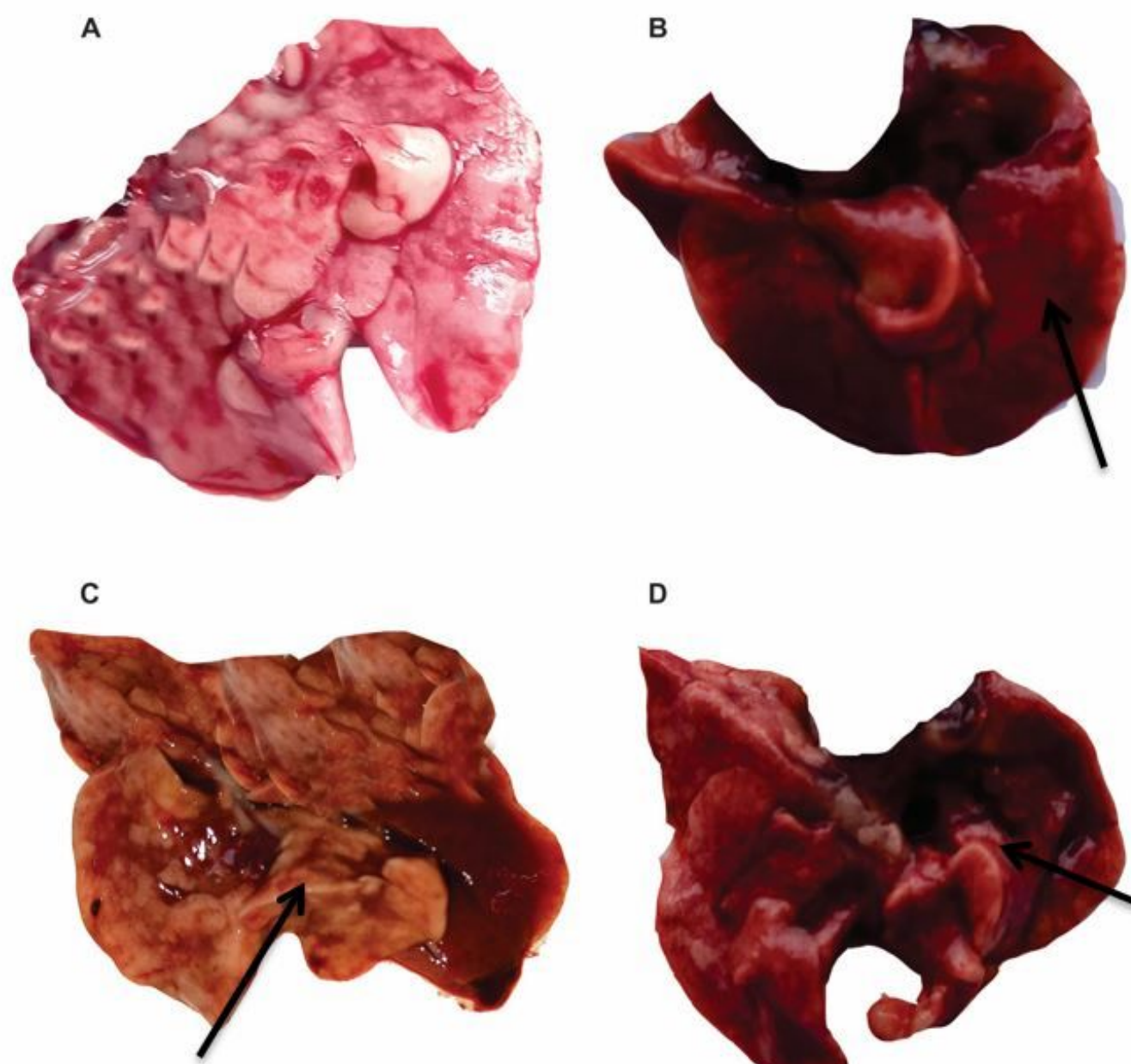

D
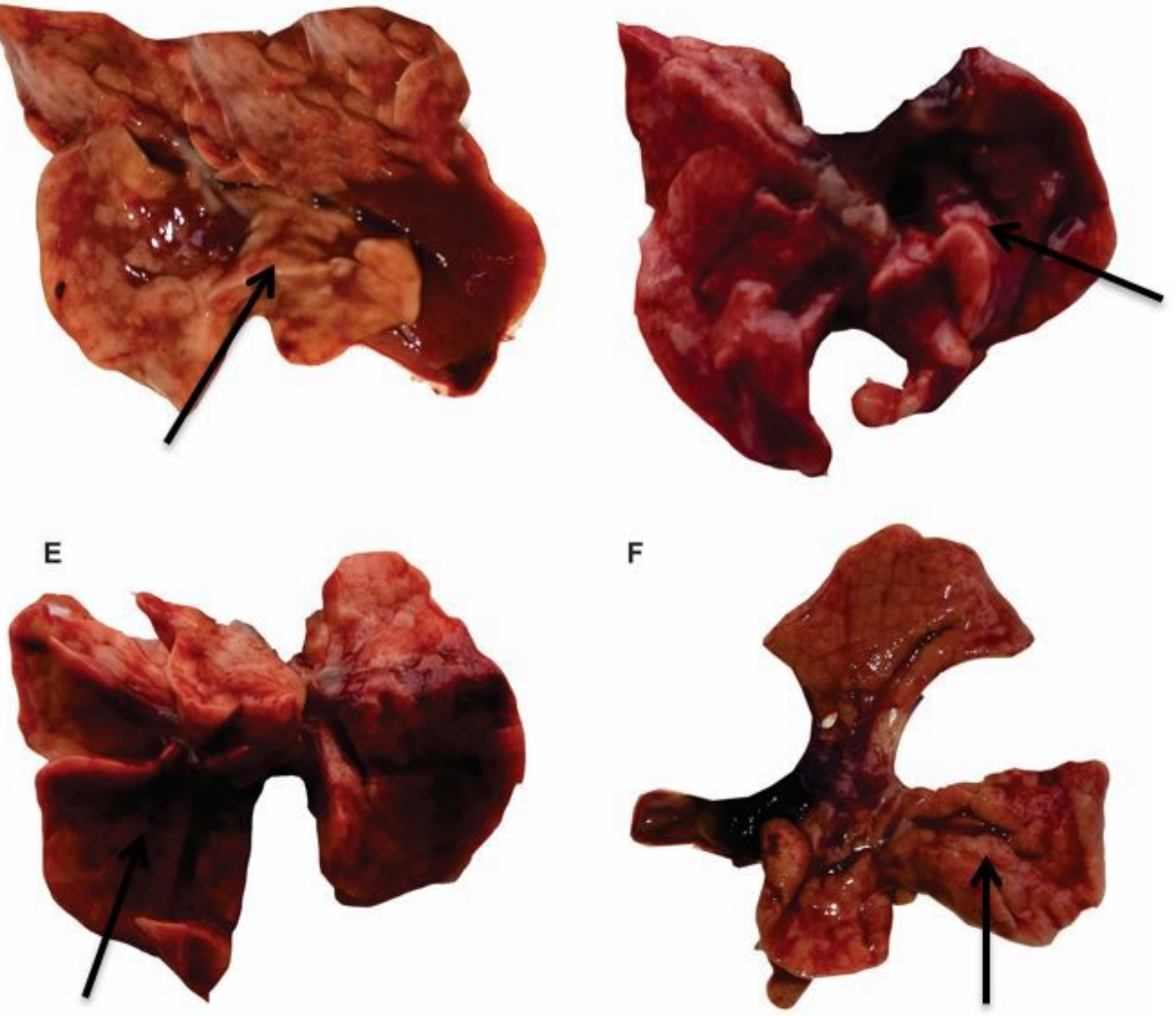

\section{Figure 2}

Shows lung of rat administered water (A), anthracene in fish; $75 \mathrm{mg} / \mathrm{kg}(\mathrm{B})$, anthracene in DMSO; 50 $\mathrm{mg} / \mathrm{kg}, 25 \mathrm{mg} / \mathrm{kg}, 12.5 \mathrm{mg} / \mathrm{kg}$ (C, D and E respectively), and DMSO; $30 \mathrm{mg} / \mathrm{kg}(\mathrm{F})$ for a period of 21 days. Arrows show affected tumour lesions. 


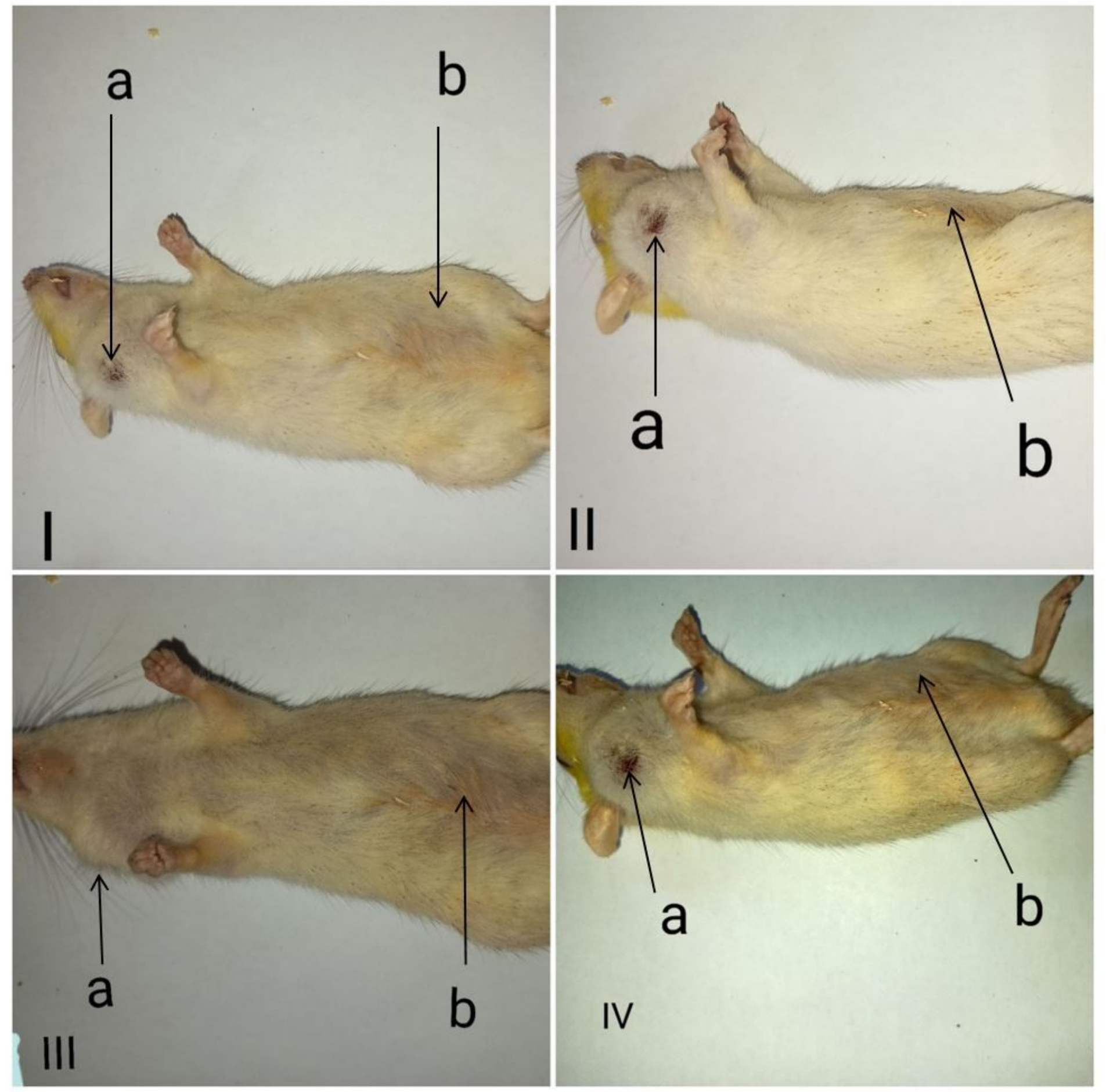

Figure 3

Rats I - IV administered $50 \mathrm{mg} / \mathrm{kg}$ body weight of anthracene in DMSO for 21 days, showing edema of superior vena cava (a) and cyanosis (b). 

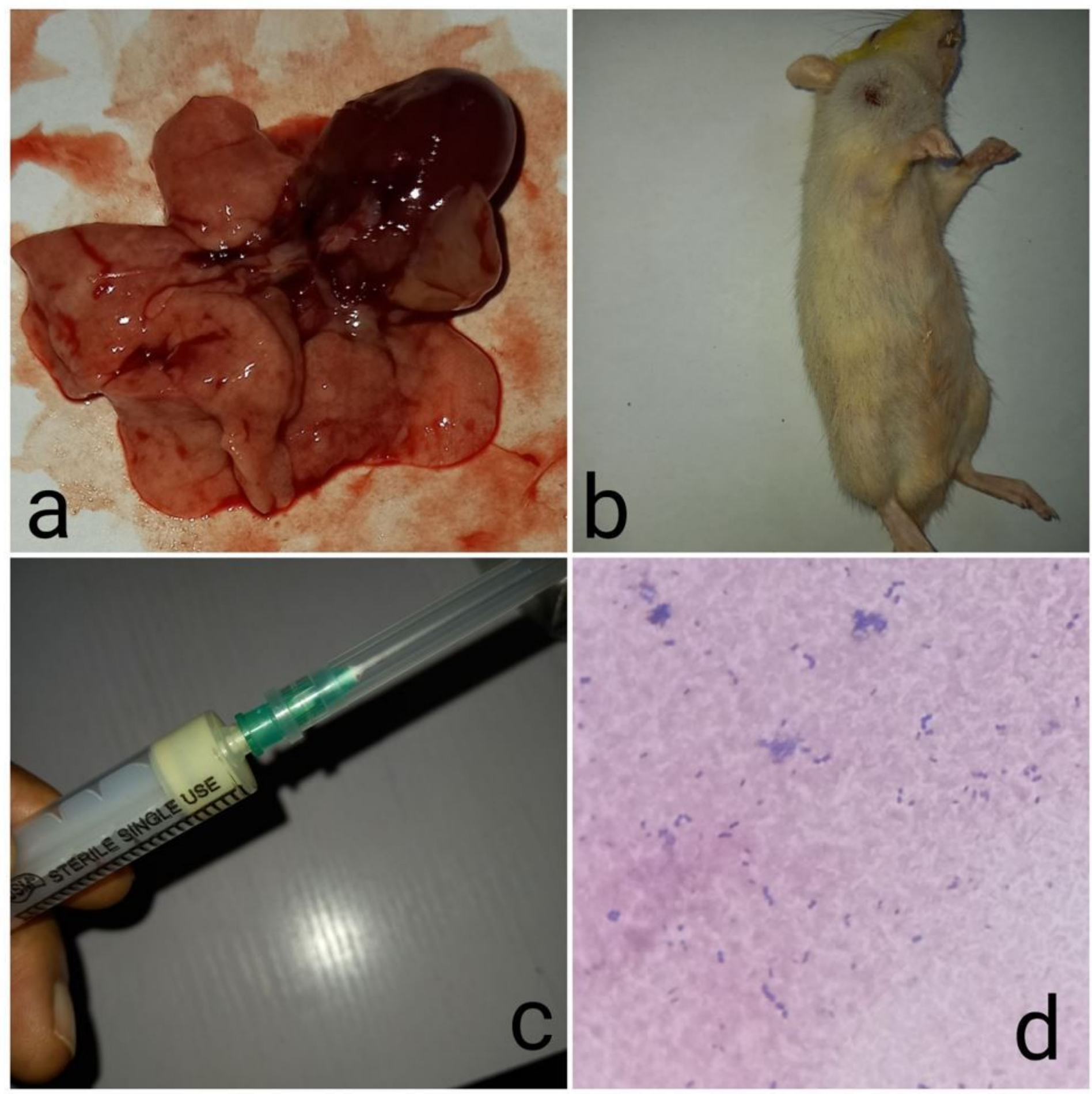

\section{Figure 4}

Showing lung and heart of rat (a), with superior vena cava (b), purulent exudates collected from superior vena cava (c) and Gram staining reaction (gram negative bacilli and yeast cells) from aspirates (d) of rats administered $50 \mathrm{mg} / \mathrm{kg}$ anthracene in DMSO.

\section{Supplementary Files}


This is a list of supplementary files associated with this preprint. Click to download.

- Plates.docx 